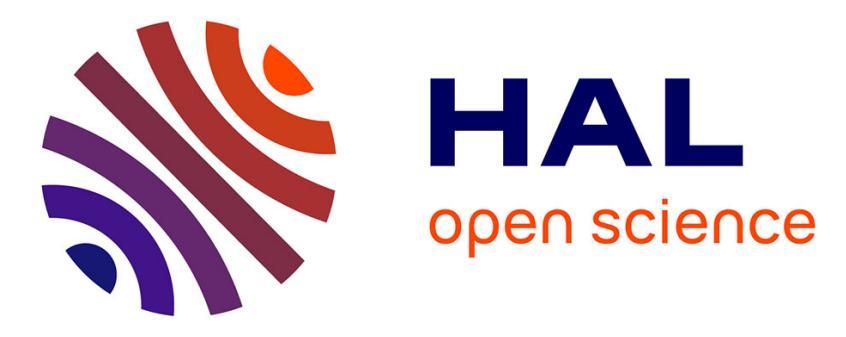

\title{
Mini Factory: A Successful Model for European Furniture Industry?
}

Marco Seregni, David Opresnik, Christian Zanetti, Marco Taisch, Fred Voorhorst

\section{To cite this version:}

Marco Seregni, David Opresnik, Christian Zanetti, Marco Taisch, Fred Voorhorst. Mini Factory: A Successful Model for European Furniture Industry?. IFIP International Conference on Advances in Production Management Systems (APMS), Sep 2014, Ajaccio, France. pp.571-578, 10.1007/978-3662-44733-8_71. hal-01387325

\section{HAL Id: hal-01387325 \\ https://inria.hal.science/hal-01387325}

Submitted on 25 Oct 2016

HAL is a multi-disciplinary open access archive for the deposit and dissemination of scientific research documents, whether they are published or not. The documents may come from teaching and research institutions in France or abroad, or from public or private research centers.
L'archive ouverte pluridisciplinaire HAL, est destinée au dépôt et à la diffusion de documents scientifiques de niveau recherche, publiés ou non, émanant des établissements d'enseignement et de recherche français ou étrangers, des laboratoires publics ou privés.

\section{(c)(1)}

Distributed under a Creative Commons Attribution| 4.0 International License 


\title{
Mini factory: a successful model for European furniture industry?
}

\author{
M. Seregni ${ }^{1}$, D. Opresnik ${ }^{1}$, C. Zanetti ${ }^{1}$, M. Taisch ${ }^{1}$, F. Voorhorst ${ }^{2}$ \\ ${ }^{1}$ Politecnico di Milano, Piazza Leonardo Da Vinci 32, 20133, Milan, Italy \\ ${ }^{2}$ Scuola universitaria professionale della Svizzera italiana - SUPSI \\ Galleria 2 CH - 6928, Manno, Switzerland \\ \{marco.seregni, david.opresnik, cristiano.zanetti, \\ marco.taisch\}@polimi.it; fred.voorhorst@supsi.ch
}

\begin{abstract}
Manufacturing system based on mini factory is one of the modern pervasive production models spreading as a response to demand for customized products with low cost and fast delivery time. However, as the term is far from being uniform and unique, its application in research and industry by managers is still challenging and represents somehow a riddle. Consequently, the various meanings associated with the term mini factory in literature are critically assayed. The results depicted three main areas of the model of mini factory: "Work organisation model", "Agile Assembly Architecture" and "Distributed mini factories network". Steming out from the third model, the possibility of using the mini factory model presented by Reichwald, Stotko \& Piller was explored. Indeed, due to its characteristics, this model seems to be able to respond more effectively to the challenges in the European furniture sector, in particular for SMEs.
\end{abstract}

Keywords: Mini factory, Distributed mini factories network, transnational strategy, Furniture

\section{Introduction}

The turnover of the European furniture industry in 2011 has been estimated at 90 billions of euro, with a total of 130.000 companies, consisted almost entirely of local small enterprise [1]. These data demonstrate the great importance of this sector both for the EU economy and its relevance among global furniture industry, where EU has a major role, among others, due to its ability to influence international fashion and design trends [2]. However, domestic demand, particularly in Western Europe, suffered a shock in 2009, due to the global crisis. Meanwhile, the growth of the global competition, particularly in the segments with lower unit value, caused a massive shift of production from EU countries to the Far East to reduce the overall production costs and, especially, labour ones [3].

In order to respond to the abovementioned challenges, European manufacturers have to radically change the production system paradigm. Especially to be able to satisfy the customers' dynamic needs and thus to increase the added value of their 
products. In this sense, the development of production system based on mini factories could be an effective solution, able to ensure higher performance than centralized mass production. However, due to the variety of models named mini factory, it is completely clear what exactly represents such model. Hence, the aim of this paper is twofold. First, it aims to clarify the term mini factory, while secondly it aims to identify the benefits of such models and to evaluate the possibility of implementation of this innovative production organization that can help European furniture SMEs to face the competition of the big international competitors. In order to fulfil those aims, the mini factory models are first categorized. Thus, as a result of the literature review three classes have been identified: Work organization model, Agile Assembly Architecture and Distributed mini factories network. In a second step, this paper explores potential benefits of the mini factory model proposed by Reichwald, Stotko \& Piller [4], belonging to the third of the above mentioned categories. Finally, this model is evaluated for its potential applicability onto the field of European furniture, where customization is growing on importance.

Consequently, this article consists of two sections: the analysis of the literature and the verification of the adaptability and the potential benefits of the model of distributed mini factory networks in the field of furniture in Europe.

\section{$2 \quad$ Mini factory models}

An analysis of the manufacturing models identified as mini factory has been conducted using as keywords "mini factory" and "minifactory" on scientific databases Scopus, Web Science and Google Scholar. The most evident result emerging from this activity was the presence of this term in many areas that do not belong to manufacturing area; this issues was solved by narrowing the spectrum of research fields related to the industrial world. Taking as example Scopus database, only documents belonging to the subject areas "Engineering", "Computer Science", "Business , Management and Accounting", "Economics, Econometrics and Finance" have been selected and analyzed. Furthermore, this literature review showed a substantial lack of a unique and universally recognized definition of mini factory; on the contrary, it highlighted a strong variability in terms of characteristics and peculiarities of the models matched to that term. Due to this result, before proceeding with the study of mini factory characteristics compared with the challenges of European furniture industry, it was necessary to sort and classify the different models and case studies identified in the research. For this reason models presented under the name of mini factory are categorized in three classes: work organization model, Agile Assembly Architecture and Distributed Manufacturing Network.

\subsection{Mini factory as "work organisation model"}

Since the 80 's the term mini factory has often been associated with innovative model for the innovation of work organisation. Ickis, Edelberg \& Morales in 2000 in the description of the organizational changes implemented by the company TANIC during the second half of the 90s, the Nicaragua subsidiary of British American Tobacco , 
identified mini factory as "[...] a manufacturing cells with sequential and distribution of compact equipment and personnel" [5]. Gilbert, Raulet Teglborg \& Crozet in 2013, describing the change in the organization of FAVI value chain activities, a French company specialized in the production of copper alloys, defined the mini factory as "[...] an island of production located in a particular area of the factory containing all the equipment and processes dedicated to a particular client" [6]. These two cases show a commonality in the goals, but a diversity in the organizational dimension. In fact, both cases' primary objective is the increase in the quality of the product, in TANIC as a response to decreasing trend in output quality while in FAVI as response to the high competition of Asian manufacturer, advantage on the cost side and resulting in aggressive pricing policies. Whereas for the organizational prospective the two cases show a substantial difference in the logic with which the mini-factories were created: in the first case mini factories are process-based while in the second they are customer-based.

In conclusion mini factory models included in this class can be defined as production organization with few hierarchical levels organized in teams, based on high job enrichment and enlargement; these units manage all production activities, including support ones needed for the completion of the customer's order.

\subsection{Mini factory as "Agile Assembly Architecture"}

The models of mini factory that fall in this category do not refer to an entire production system, but concentrate on a specific phase of manufacturing production: the assembly. In particular in this area have been included models with both technological and functional features that get them in contact with FAS (Flexible Assembly System), defined as "an integrated, computer-controlled, robotic assembly of machines and automatic and programmable and automatic devices transport and handling, able to mount simultaneously medium volumes of a variety of different assemblies" [7].

Muir, Rizzi \& Gowdy defined a system mini factory that are developing as "Potentially large collection of mechanically, computationally and algorithmically robotic modules [...]" [8]; furthermore they defined "high precision, self calibrating, agent based, distributed assembly system" [9].

Gaugel, Bengel \& Malthan associated Mini Factory with "[...] a marketable, miniaturized highly flexible micro-assembly system capable of reproducing the correct size proportions between a product and its production environment and also able to intelligently integrated which had earlier run separate processes" [10].

The abovementioned models can be seen as FAS with extremely small (a room of an apartment or even a desk) through the use of miniaturized machinery, equipment and components, thus equalizing to concept of Microfactory [11]. These solutions could represent a technical instrument for facing assembly challenges related to high demand for customized products; however, as automated systems managed by an artificial control, they have a degree of flexibility that does not allow to work any type of piece. Consequently, they require a prior standardization of components in order to operate effectively in a customized production. 
In terms of output these systems are widely used for the realization of products of very small dimensions, which need for high accuracy, in some cases in the vicinity of microns; for instance Printed Circuit Boards (PCB) is a product for which these assembly models are widespread.

\subsection{Mini factory as "Distributed mini factories network"}

In 2005 Reichwald, Stotko, \& Piller defined mini factory as "[...] a designed scalable, modular, geographically distributed unit that is networked with other units of this type" [4]. In their model mini factory should performs all operations needed for the effective completion of the customer's order:

- design with an high involvement of customer and supported by user friendly tools;

- customized manufacturing on the basis of the customer's requests recorded in the previous phase;

- delivery, with the aim to guarantee a short delivery time;

- afters sales activities, such as repair, maintenance and other supplementary services.

The authors focus on the importance of networking all mini-factories installed with the aim of sharing various types of information (i.e. customer requirements, solutions to problems in mini factory management), thus giving the opportunity to personnel to access to a huge and global knowledge; moreover, localization near customers supports the growth of repeating purchase, hence increasing the customer retention rate. According to Zaeh and Wagner [12] this distributed instantiation of mini factories can also have economic positive impact by reducing logistic costs and delivery time.

The above described model also includes a central command unit which carries out support to the network of mini factories, such as the sourcing of standard components of the product, operators' training and definition of the basic characteristics of the product. Within mini factory, modularity means that each local unit is composed of modules that can be combined together thanks to their standard interfaces; thus local specificity of each mini-factory is easily ensured by a combination of these standard modules.

\section{Model application onto the European furniture sector}

The strong global competition and in particular the Asian player has pushed European manufacturers looking for ways to differentiate their offering in order to justify an higher price; this goal has markedly increased the relevance of the following abilities:

- quick and on demand supply;

- rapid response to changing tastes;

- customer support services. 
Another very marked feature in the European furniture country in is the strong diversity in national markets, both in terms of design style, product mix and materials; thus selling into these countries requires a high knowledge of local customers and a large network of contacts. From a structural point of view, this sector is mostly composed, with the exception of a few international players, by SMEs, who are then more difficult to respond to these challenges. The model of distributed mini factories network presented, due to its characteristics, could be helpful for SMEs for meeting the growing need for customization of European furniture sector and eventually interfacing with different national markets.

\subsection{Customization and transnational strategy in furniture industry}

Reichwald, Stotko \& Piller suggested their model of mini factory was particularly suitable "for creating customized products and services if a company's situation is characterized by a high degree of variability and specificity". For "specificity" the authors mean that products would withstand an high depreciation if rejected by the specific customer. Clearly this concept is strongly linked to customization, as the customized product means that specific product has a low value for other customers, even at the limit zero. Research conducted by Lihra, Buehlmann \& Beauregard in 2008 showed that customized portfolio could be implemented as a successful strategy for US producers in order to face competing with low-cost offshore manufacturers, although with different impacts in different segments" [13].

Focusing on European furniture market, it presents a deep fragmentation in many segments with different features, linked with different customer's profile, as SERIN \& ANDAÇ analysis within Turkish furniture showed [14]. According to a classification based on the intended use of furniture, at a very general level the sector can $b$ partitioned into two segments: office furniture and domestic ones. Surely, customization is a competitive lever of primary importance much more in the second segment as a result of a variety and heterogeneity of characteristics required, ranging from functionality to aesthetics. More specifically, for its characteristics, distributed mini factories network can adapt better to specific groups of domestic furniture consumers [15] requiring customization in terms of size (i.e. "middle age singles") or in terms of style (i.e. "young couples").

In addition to customization needs, furniture industry in Europe has a strong heterogeneity among national markets [16], as confirmed by Tammela, Cane \& Helo, a study on Time-Based Competition strategies of Brazilian and Scandinavian furniture companies that highlighted cultural diversity of customers and business partners was a key issue for strategic decision [17]. Thus a transnational strategy in which a company "[...] strives for global efficiency without losing on the advantages of offering a customized product tailored to local or regional habits" [18], could be a potentially successful solution. Consequently, distributed mini factories network, according to Reichwald, Stotko and Seifert conclusion [18], could be an effective way for the implementation of transnational strategy within European sector. 


\subsection{Potential advantages for furniture SMEs}

Due to its characteristics, distributed mini factories network represents an intermediate solution with some aspects in common to large international companies and others with local SMEs; in particular SMEs, those represents more than $95 \%$ of the European furniture companies, could achieve competitive advantages [19] by joining a distributed mini factories network:

- centralized management of the support activities could enable SMEs to take cost advantage due to economies of scale;

- thanks to the integration between the design and production activities, and the logic of local lean supply chain, several inconsistencies between company's operations can be avoided, thus reducing significantly of the overall delivery time and its variance; this potential advantage has an enormous importance for producers in mature furniture markets in response to competitive pressure from manufacturers in the Far East, such as Mitchell \& Watt stressed with reference to the American market $[20]$

- SMEs can obtain significant benefits in the knowledge management, due to the greater amount of information that can be accessed within the network of mini factories. Indeed, thanks to the network in which it is inserted, SMEs are able to access a variety of resources comparable to that of large firms. At the same time in this solution, single manufacturer is able to interact with the customer while obtaining from him complete information and a valuable feedback [21];

- providing to the customer a set of information about the product marked higher than any kind of catalogue, thus responding to increasing furniture customer's need for information due to technological knowledge, social values and socio-economic changing [22];

- reducing the downstream supply chain levels, thus increasing manufacturers' strength against furniture retailers, which has arisen their role over the past years due to their ability to interact directly with the customer [23].

\section{$4 \quad$ Limitations and further research}

The main limitation of this article is that it is on a conceptual level. This means that the model has not yet been applied and its success evaluated. However, the validity of the conceptualization has been reinforced by: a) working with widely recognized models, b) by working with reliable characteristics from the furniture industry, c) taking into account the trends in manufacturing as also on the furniture market and d) clearly defining boundaries of the mini factory model. The second limitation is that it does not take into account any more specific part of the furniture sector. However, due to the novelty in this field, the possibility from a general perspective had to be assayed first. Consequently, one of the next steps in terms of further research will be to focus on a specific sub-segment of the furniture industry. Furthermore, further research will be carried out in order to define more in detail the operational characteristics for the instantiation of a furniture mini-factories network, such as the supply 
chain, production planning logics, basic designs concepts. In particular, as demonstrated by some studies ([24],[25]), there is a growing attention of the customer with regard to environmental sustainability, which translates into a reward in terms of willingness to pay; thus, future research will explore the implications on mini factory model for ensuring high green performance.

\section{$5 \quad$ Conclusions}

In this article, the main models of the mini factory were identified and scrutinized, from which three main types were more closely depicted. The model of Reichwald, Stotko \& Piller [4] has been identified to be the most proper one for further application. Based on the comparison between competitive conditions that were deemed optimal for the mini factory and the characteristics of the sector shows, that the model is applicable to the furniture industry, in particular for SMEs. The results of the analysis showed among others that that the furniture has the market condition suitable for the effective implementation of the distributed mini factory network. This means that the production model in question can increase the competitive advantage of the manufacturing enterprises in the furniture industry, thus indicating that this model is a viable answer for those manufacturers in time of economic crisis, supply surplus and lack of demand.

\section{Acknowledgements}

The work presented here is part of the project "CTC- Close To Customer"; this project has received funding from the European Union's Seventh Framework Programme for research, technological development and demonstration under grant agreement no FoF.NMP.2013-6 608736 - CTC.

\section{References}

1. Eurostat. (2011). http://epp.eurostat.ec.europa.eu/portal/page/portal/statistics/themes. From www.Eurostat.

2. Oliver, R. (s.d.). www.itto.int/...download/topics_id=3466\&no=1. from da www.itto.int.

3. "European Sector Monitor of the wood/furniture industry"

4. Reichwald, R., Stotko, C. M., \& Piller, F. T. (2005). Distributed mini-factory networks as a form of real-time enterprise: concept, flexibility potential and case studies. In The Practical Real-Time Enterprise (pp. 403-434). Springer Berlin Heidelberg.

5. Ickis, J. C., Edelberg, G., \& Morales, M. (2000). Tanic. Journal of Business Research, 50(1), 123-137. doi:10.1016/S0148-2963(98)00109-X

6. Gilbert, P., Raulet Crozet, N., \& Teglborg, A. C. (2013). Work Organisation and Innovation-Case Study: FAVI, France.Dublin: European Foundation for the Improvement of Living and Working Conditions

7. Garetti M., Taisch M. (1997), Automatic production systems, in italian, original title: Sistemi di produzione automatizzati, 2nd ed., CUSL, Milan 
8. Muir, P. F., Rizzi, A. A., \& Gowdy, J. W. (1997, December). Minifactory: A precision assembly system adaptable to the product life cycle. In Intelligent Systems \& Advanced Manufacturing (pp. 74-80). International Society for Optics and Photonics.

9. Kume, S., \& Rizzi, A. A. (2001). A high-performance network infrastructure and protocols for distributed automation. In Robotics and Automation, 2001. Proceedings 2001 ICRA. IEEE International Conference on (Vol. 3, pp. 3121-3126). IEEE.

10. Gaugel, T., Bengel, M., \& Malthan, D. (2004). Building a mini-assembly system from a technology construction kit. Assembly automation, 24(1), 43-48.

11. Okazaki, Y., Mishima, N., \& Ashida, K. (2004). Microfactory-concept, history, and developments. Journal of Manufacturing Science and Engineering, 126(4), 837-844.

12. Zäh, M. F., \& Wagner, W. (2003). Planning Mini-Factory Structures for the Close-toMarket Manufacture of Individualized Products. Proceedings of the MCPC, 3.

13. Lihra, T., Buehlmann, U., \& Beauregard, R. (2008). Mass customisation of wood furniture as a competitive strategy. International Journal of Mass Customisation, 2(3), 200-215.

14. SERIN, H., \& ANDAÇ, T. (2012). An investigation of the preferences of furniture consumers depending on education and age factors in Turkey. African Journal of Business Management, 6(22), 6658-6666.

15. CBI. (2007). The domestic furniture market in the EU

16. Arbeit und Leben Bielefeld e.V. (DGB/VHS) (2009). European Sector Monitor of the wood/furniture industry

17. Tammela, I., Canen, A. G., \& Helo, P. (2013). Time-based competition: Relation to multiculturalism and logistics in international furniture companies.Benchmarking: An International Journal, 20(5), 588-606.

18. Reichwald, R., Stotko, C. M., Seifert, S., \& TUM-AIB, L. (2003). Internationalizing Mass Customization-Minifactories as a transnational solution. In Proceedings of the 2nd Interdisciplinary World Congress on Mass Customization and Personalization.

19. Frohlich, M. T., \& Dixon, J. R. (2001). A taxonomy of manufacturing strategies revisited. Journal of Operations Management, 19(5), 541-558.

20. Mitchell, P., \& Watt, H. (2010). Strategies for the New American Furniture Industry. North Carolina: Cooperative Extension.

21. Buehlmann, U., Bumgardner, M., \& Sperber, M. (2013). How Small Firms Contrast with Large Firms Regarding Perceptions, Practices, and Needs in the U.S. Secondary Woodworking Industry. BioResources, 8(2), 2669-2680. doi:10.15376/biores.8.2.2669-2680

22. Öztop, H., Erkal, S., \& Gunay, G. (2008). Factors Influential in Consumers' Furniture Selection and their Preferences regarding Product Features. The International Journal of Interdisciplinary Social Sciences, 23-34.

23. Lihra, T., \& Graf, R. (2007). Multi-channel communication and consumer choice in the household furniture buying process. Direct Marketing: An International Journal, 1(3), 146160 .

24. Jensen, K. (2002). Willingness to pay for environmentally certified hardwood products by Tennessee consumers (Doctoral dissertation, University of Tennessee).

25. Aguilar, F. X., \& Vlosky, R. P. (2007). Consumer willingness to pay price premiums for environmentally certified wood products in the US. Forest Policy and Economics, 9(8), $1100-1112$. 